\title{
Odpowiedzialność przedsiębiorcy za niedostarczanie informacji i dokumentów na żądanie Prezesa UOKiK - kilka refleksji po decyzji w sprawie Engie
}

\section{Spis treści}

I. Wprowadzenie

II. Wymagany standard żądania kierowanego przez organ antymonopolowy

1. Obligatoryjne elementy żądania

2. Cel żądania

3. Zakres żądania

4. Zakres obowiązku przedsiębiorcy

5. Sankcja za naruszenia obowiązku określonego w art. 50 ust. 1 uokik

III. Podsumowanie

\section{Streszczenie}

Artykuł zawiera analizę przyjętych w polskim porządku prawnym rozwiązań regulujących tryb żądania informacji i dokumentów przez Prezesa Urzędu Ochrony Konkurencji i Konsumentów (dalej: Prezes UOKiK). W pierwszej części artykułu autor omawia podstawowe standardy, które powinno spełniać żądanie organu antymonopolowego, w odniesieniu do formułowanego w nim zakresu żądania i celu, uwzględniając w szczególności wytyczne wynikające z orzecznictwa unijnego. Autor rozważa zakres obowiązku wynikającego z art. 50 ust. 1 ustawy o ochronie konkurencji i konsumentów (dalej: uokik), poddając krytyce rozwiązanie, które uniemożliwia w praktyce kwestionowanie żądań organu antymonopolowego bez ryzyka narażenia się na surowe sankcje finansowe. Omówione zostają również propozycje de lege ferenda, których celem byłoby zapewnienie przedsiębiorcom odpowiedniego standardu ochrony praw podstawowych w związku z procedurą przedkładania informacji i dokumentów żądanych przez organ antymonopolowy. Druga część artykułu poświęcona jest zagadnieniom dotyczącym kar pieniężnych za naruszenie obowiązku, o którym mowa w art. 50 ust. 1. Autor omawia funkcjonujące obecnie rozwiązania prawne i wskazuje na potrzebę wprowadzenia określonych zmian legislacyjnych w przyszłości. Analizie poddana została również praktyka polskiego organu antymonopolowego w zakresie nakładania kar za naruszenie obowiązku wynikającego z art. 50 ust. 1 uokik.

Słowa kluczowe: naruszenia proceduralne; niedostarczenie dokumentów; nieudzielenie informacji; kara pieniężna; żądanie udzielenia informacji.

JEL: K21, K42, L49

* Radca prawny; partner w kancelarii Sołtysiński, Kawecki \& Szlęzak. Autor jest pełnomocnikiem EEHMS w postępowaniach przed Prezesem UOKiK. E-mail: krzysztof.kanton@skslegal.pl. 


\section{Wprowadzenie}

W listopadzie 2019 r. na stronie internetowej Urzędu Ochrony Konkurencji i Konsumentów (dalej: UOKiK) pojawił się komunikat informujący o nałożeniu na spółkę Engie Energy Management Holding Switzerland AG (dalej: EEMHS) najwyższej w historii urzędu kary pieniężnej wynoszącej $172 \mathrm{mln}$ zł (równowartość $40 \mathrm{mln}$ euro) ${ }^{1}$. Kara nałożona na EEMHS nie była bynajmniej sankcją za uczestnictwo w długoletnim kartelu bądź nadużywanie pozycji dominującej mające daleko idące, negatywne konsekwencje dla rynku. Podstawą nałożenia kary przez Prezesa UOKiK był art. 106 ust. 2 pkt 2 uokik - EEMHS została ukarana za naruszenie proceduralne polegające na odmowie przekazania dokumentów zażądanych przez organ antymonopolowy (umów zawartych z kontrahentem EEMHS).

Żądanie Prezesa UOKiK zostało wystosowane w związku z prowadzonym przez organ antymonopolowy postępowaniem mającym na celu ustalenie czy EEHMS nie naruszyła przepisów poprzez utworzenie wraz z innymi przedsiębiorcami nowego przedsiębiorcy bez uprzedniej zgody Prezesa UOKiK. Spółka zakwestionowała otrzymane przez nią żądanie jako wadliwe, wskazując m.in. na uchybienia dotyczące prawidłowego wyjaśnienia celu wezwania. Prezes UOKiK uznał, że wątpliwości te były nieuzasadnione. W konsekwencji Prezes UOKiK nałożył na EEHMS surową karę pieniężną, wskazując, że jest ona uzasadniona, uwzględniając, iż spółka nie przedłożyła żądanych przez organ antymonopolowy informacji.

Uprawnienie Prezesa UOKiK do zwracania się do przedsiębiorców o przekazanie określonych informacji oraz dokumentów jest niezbędne, aby organ antymonopolowy mógł realizować nałożone na niego zadania. Uprawnienia w tym zakresie dla krajowych organów antymonopolowych funkcjonują powszechnie w państwach, w których przyjęto regulacje dotyczące ochrony konkurencji. Szerokie kompetencje w tym zakresie posiada również Komisja Europejska². Jak wskazują opracowania OECD, „chociaż terminologia różni się pomiędzy jurysdykcjami, wnioski o udzielenie informacji (requests for information) są jednymi z najczęściej wykorzystywanych w praktyce narzędzi dochodzeniowych"3.

Rozstrzygnięcie Prezesa UOKiK w sprawie EEMHS skłania jednak do refleksji czy polskie przepisy regulujące tryb żądania informacji i dokumentów zapewniają przedsiębiorcom odpowiedni standard ochrony praw podstawowych, w szczególności prawo wolności od samooskarżania się oraz prawo do sądu. W kontekście wspomnianej decyzji bardzo aktualne stają się również pytania o prawidłowość ustawowych rozwiązań w zakresie sankcji za naruszenia proceduralne oraz samego podejścia UOKiK do nakładania kar pieniężnych. Do rozważenia pozostaje zatem kwestia czy i w jakim zakresie pożądane są zmiany obecnych regulacji.

W niniejszym artykule chciałbym zwrócić uwagę na pewne mankamenty obecnych rozwiązań prawnych i wskazać na wiążące się z nimi praktyczne ryzyka dla przedsiębiorców. Należy

\footnotetext{
Dec. Prezesa UOKiK z 7.11.2019 r. DKK 217-2019.

2 W postępowaniach antymonopolowych dotyczących naruszenia art. 101 i 102 TFUE upoważnienie do żądania informacji i dokumentów zostało ujęte w art. 18 rozporządzenie 1/2003, zgodnie z którym „w celu wypełniania obowiązków wyznaczonych niniejszym rozporządzeniem Komisja może zwrócić się do przedsiębiorstw lub związków przedsiębiorstw o dostarczenie wszelkich koniecznych informacji, występując ze zwykłym żądaniem informacji lub w drodze decyzji”. W sprawach dotyczących koncentracji uprawnienia Komisji Europejskiej reguluje art. 11 rozporządzenia Rady Nr $139 / 2004$ z dnia 20 stycznia 2004 r. w sprawie kontroli koncentracji przedsiębiorstw (Dz. Urz. L 024/1), który stanowi, że Komisja w celu wykonania zadań powierzonych jej w rozporządzeniu, może za pośrednictwem prostego wniosku lub decyzji, uzyskać wszystkie konieczne informacje od rządów i właściwych władz państw członkowskich, od osób określonych w art. 3 ust. 1 lit. b), oraz od przedsiębiorstw i związków przedsiębiorstw.

3 Global Forum on Competition INVESTIGATIVE POWERS IN PRACTICE - Breakout session 2: Requests for Information: Limits and Effectiveness - Issues Note by the Secretariat. Pozyskano z: https://one.oecd.org/document/DAF/COMP/GF(2018)8/en/pdf.
} 
jednocześnie poddać pod rozwagę kilka propozycji de lege ferenda, które miałyby na celu wprowadzenie rozwiązań zmierzających do zapewnienia większej równowagi pomiędzy uprawnieniami organu antymonopolowego a prawami przedsiębiorcy w postępowaniu przed Prezesem UOKiK.

\section{Wymagany standard żądania kierowanego przez organ antymonopolowy}

\section{Obligatoryjne elementy żądania}

Zgodnie z przepisem art. 50 ust. 1 uokik każdy przedsiębiorca ma obowiązek przekazywania wszelkich koniecznych informacji i dokumentów na żądanie Prezesa UOKiK ${ }^{4}$. Żądanie to może zostać skierowane w ramach każdego z postępowań prowadzonych przez Prezesa UOKiK, w tym postępowania wyjaśniającego ${ }^{5}$. Adresatami żądania mogą być zarówno strony postępowania, jak i przedsiębiorcy, którym nie przysługuje status strony. W ujęciu podmiotowym treść przepisu art. 50 ust. 1 uokik nie powinna budzić żadnych wątpliwości: Prezes UOKiK może zwrócić się z żądaniem o przekazanie informacji i dokumentów do każdego „przedsiębiorcy” w rozumieniu uokik.

Przepis art. 50 ust. 2 uokik zawiera następujące obligatoryjne elementy żądania Prezesa UOKiK o przedstawienie informacji i dokumentów:

1) wskazanie zakresu informacji;

2) wskazanie celu żądania;

3) wskazanie terminu udzielenia informacji;

4) pouczenie o sankcjach za nieudzielenie informacji lub za udzielenie informacji nieprawdziwych lub wprowadzających w błąd.

Sytuacje, w których żądanie nie zawiera przynajmniej zwięzłego odniesienia do wszystkich elementów żądania, o których mowa w art. 50 ust. 2 uokik, zdarzają się w praktyce bardzo rzadko. Organ antymonopolowy, co do zasady, skrupulatnie przestrzega, aby w kierowanych przez niego żądaniach elementy wskazane w art. 50 ust. 2 uokik zostały (przynajmniej formalnie) ujęte. Nie oznacza to wszakże, że we wszystkich przypadkach możemy mieć do czynienia z prawidłowo sformułowanym żądaniem. Wzorzec prawidłowo sformułowanego wezwania wyznacza bowiem nie tylko sama ustawa, która formułuje określone minimum dotyczące niezbędnych elementów żądania. Należy uwzględnić również wymóg respektowania standardów sprawiedliwości proceduralnej i zapewnienia odpowiednich gwarancji prawa przedsiębiorcy do obrony.

Uwzględniając powyższy aspekt, nasuwa się pytanie, co powoduje, że żądanie organu antymonopolowego należy uznać za wadliwe, pomimo że formalnie wydaje się spełniać wymogi określone w art. 50 ust. 2 uokik? W mojej ocenie z wadliwością możemy mieć do czynienia przede wszystkim w następujących sytuacjach:

- $\quad$ żądanie nie zawiera precyzyjnego uzasadnienia dotyczącego celu wezwania;

- żądanie odnosi się do informacji lub dokumentów, których zakres nie jest związany z prowadzonym postępowaniem, a przez to nie są spełnione wymogi konieczności i proporcjonalności.

\footnotetext{
W myśl art. 49 uokik możliwe jest również kierowanie przez UOKiK tzw. wezwań miękkich, w których organ antymonopolowy zwraca się do przedsiębiorcy z prośbą o dobrowolne przekazanie określonych danych.

Wyr. SN z 2.12.2008 r., III SK 15/08.
} 


\section{Cel żądania}

Kluczowym aspektem przy ocenie prawidłowości żądania jest weryfikacja jego uzasadnienia. Należy podzielić tu postulat - formułowany w orzecznictwie unijnym ${ }^{6}$ - aby organ antymonopolowy formułował cel żądania w sposób wystarczająco precyzyjny, który (i) umożliwia weryfikację czy istnieje związek między żądanymi informacjami lub dokumentami a domniemanym naruszeniem przepisów, a zatem czy dane objęte żądaniem są faktycznie konieczne na potrzeby prowadzonego przez UOKiK postępowania oraz (ii) wyjaśnia powody przedstawienia żądania w sposób pozwalający jego adresatowi na ocenę przyczyny żądania informacji w celu uniknięcia ewentualnego samooskarżenia.

W tym kontekście zastrzeżenia budzi praktyka UOKiK polegająca na formułowaniu uzasadnień w sposób bardzo ogólny, w niektórych przypadkach ograniczająca się do stwierdzenia, że organ antymonopolowy zwraca się do przedsiębiorcy z prośbą o przekazanie informacji „w celu wyjaśnienia okoliczności sprawy” lub „w związku z prowadzonym postępowaniem”. Za nietrafne należy uznać stanowisko wyrażone w literaturze i powoływane przez UOKiK w swoich rozstrzygnięciach (m.in. w decyzji dotyczącej EEMHS), zgodnie z którym określenie celu żądania należy rozumieć jako wymóg jednoznacznego wskazania przedmiotu postępowania, którego potrzebom mają służyć żądane materiały oraz strony lub stron tego postępowania (Kruger, 2016, s. 877).

Należy postulować, aby uzasadnienie żądania wykraczało w praktyce poza lakoniczną informację dotyczącą samego przedmiotu postępowania. Za takim podejściem opowiadają się liczni przedstawiciele doktryny. Podkreśla się, że

niewystarczające wydaje się, przyjęte w praktyce Prezesa UOKiK, wskazywanie wyłącznie na potrzeby jakiego konkretnego postępowania potrzebne są żądane informacje, z czego ma wynikać, że informacje te są konieczne (...) Takie wskazanie ma bowiem w swojej istocie charakter ogólny - określa jedynie w związku z jakim postępowaniem informacje te są żądane. Nie zawiera natomiast uzasadnienia, do czego konkretnie mają one zostać użyte (np. jaką okoliczność mają udowadniać) oraz jakie czynności na ich podstawie zamierza podjąć Prezes UOKiK. (Bernatt, 2011, s. 185)

Powołane powyżej stanowisko podzielają także C. Martysz (2009, s. 1221) oraz autorzy komentarza pod redakcją C. Banasińskiego i E. Piontka (Skoczny, 2014, s. 931), którzy podkreślają, że cel żądania powinien być określony możliwie precyzyjnie, tak aby jego adresat wiedział czemu mają służyć żądane informacje i czy mogą one zostać wykorzystane przeciwko niemu. Powyższe podejście do zakresu obowiązków Prezesa UOKiK dotyczących określenia celu wezwania zostało potwierdzone w komentarzu do ustawy pod redakcją T. Skocznego (2014, s. 931). Cel zbierania informacji powinien być określony możliwie dokładnie, aby poinformować adresata wezwania o planowanym użyciu żądanych dokumentów lub informacji, w celu umożliwienia przedsiębiorcy ustalenia czy takie informacje lub dokumenty nie będą wykorzystane przeciwko niemu (Skoczny, 2014, s. 931; Banasiński i Piątek, 2009, s. 619).

Kwestie dotyczące wymogów obowiązujących Komisję Europejską (dalej: KE) w związku z formułowaniem żądań o przedłożenie informacji - w szczególności w zakresie uzasadnienia

Wyr. TSUE z 10.03.2016 r. w sprawie C-247/14 P. 
żądania - były przedmiotem orzeczeń Trybunału Sprawiedliwości Unii Europejskiej (dalej: TSUE). Bardzo ważnym rozstrzygnięciem wyznaczającym standardy, które powinny obowiązać w tym zakresie organ antymonopolowy jest wyrok TSUE w sprawie HeidelbergCement ${ }^{7}$.

Trybunał rozstrzygał spór pomiędzy KE a producentami cementu objętymi postępowaniem antymonopolowym dotyczącym zakresu informacji zażądanych przez KE. Po przeprowadzeniu kontroli u wspomnianych przedsiębiorców, KE wszczęła w 2010 r. postępowanie w sprawie domniemanych naruszeń antymonopolowych. Naruszenia te miały polegać na ograniczeniach w obrocie handlowym w Europejskim Obszarze Gospodarczym (dalej: EOG), w tym m.in. ograniczeniach w przywozie do EOG produktów pochodzących z krajów spoza EOG, podziale rynku i koordynacji cen. W dniu 30 marca 2011 r. KE wydała decyzję, na podstawie której zobowiązała m.in. spółkę HeidelbergCement do przedstawienia szczegółowych informacji w związku z prowadzonym postępowaniem. Spółka wniosła skargę o stwierdzenie nieważności decyzji, wskazując m.in., że uzasadnienie decyzji KE nie zawierało odpowiedniego wyjaśnienia domniemanego naruszenia, a sama decyzja nakładała na nią nieproporcjonalnie duże obciążenia, uwzględniając ilość wymaganych informacji oraz szczególnie uciążliwy format odpowiedzi (kwestionariusz Komisji liczył ponad 90 stron i zawierał zestawienie bardzo szczegółowych pytań). W wyniku odwołania HeidelbergCement TSUE uchylił decyzję Komisji Europejskiej, uznając wnioski spółki za uzasadnione. TSUE wskazał, że w uzasadnieniu decyzji dotyczącej wniosku o udzielenie informacji, to Komisja musi określić podstawę prawną i cel wniosku. Musi ona również określić jakie informacje są wymagane i ustalić termin, w którym należy je dostarczyć. Zobowiązanie do podania konkretnych powodów jest podstawowym wymogiem, mającym na celu nie tylko wykazanie, że wniosek dla celów informacyjnych jest uzasadniony, lecz także po to, aby umożliwić zainteresowanym przedsiębiorstwom ocenę zakresu obowiązku współpracy przy jednoczesnej ochronie ich prawa do obrony.

TSUE zauważył, że pytania skierowane przez Komisję do HeidelbergCement były wyjątkowo liczne i obejmowały bardzo różne rodzaje informacji. Jednakże samo uzasadnienie decyzji było „zwięzłe, pobieżne i ogólne” i nie pozwalało na ustalenie z dostateczną dokładnością ani produktów, których dotyczy dochodzenie, ani podejrzeń naruszenia uzasadniających przyjęcie decyzji. Jak stwierdził TSUE,

takie uzasadnienie nie pozwala danemu przedsiębiorstwu na sprawdzenie, czy żądane informacje są konieczne dla celów dochodzenia, a sądowi Unii na dokonanie stosownej weryfikacji. ${ }^{8}$

TSUE wskazał jednocześnie, że dokonując oceny uzasadnienia, należy uwzględnić jego literalne brzmienie, ale również szerszy kontekst, w szczególności informacje będące w posiadaniu przez adresata żądania (wynikające np. z postanowienia o wszczęciu postępowania). Jednakże, w tym przypadku TSUE stwierdził, że uzasadnienie decyzji wzywające do przedstawienia informacji i dokumentów było na tyle ogólne i niejasne, że niemożliwe było inne rozstrzygnięcie niż uchylenie decyzji. TSUE podtrzymał zarazem opinię Rzecznika Generalnego Nielsa Wahla, który w opinii poprzedzającej wydanie wyroku stwierdził, że fakt, iż uzasadnienie może być zbyt ogólne lub nieco niejasne w odniesieniu do niektórych aspektów, nie prowadzi do unieważnienia, jeżeli

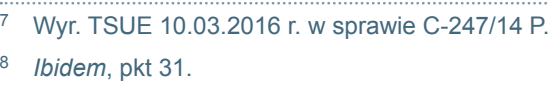

internetowy Kwartalnik Antymonopolowy i Regulacyjny 2020, nr 3(9) • www.ikar.wz.uw.edu.pl • DOI: 10.7172/2299-5749.IKAR.3.9.5 
pozostała część decyzji pozwala adresatowi i sądom UE na wystarczająco dokładne zrozumienie, jakich informacji poszukuje Komisja i jakie są tego powody. Aczkolwiek przedmiot postawionych pytań może potencjalnie „rzucić dodatkowe światło na uzasadnienie”, to w przypadku decyzji KE dotyczącej HeidelbergCement tak jednak nie było, co przemawiało za stwierdzeniem nieważności decyzji.

\section{Zakres żądania}

Precyzyjne sformułowania celu żądania umożliwia weryfikację czy zakres żądanych informacji jest rzeczywiście konieczny i niezbędny w związku z prowadzonym postępowaniem. Do wspomnianego wymogu konieczności odwołuje się uokik: w myśl art. 50 ust. 1 uokik żądanie Prezesa UOKiK powinno być zawsze ograniczone do informacji i dokumentów, które są konieczne dla prowadzenia postępowania w danej sprawie. Ograniczenie to konkretyzuje konstytucyjną zasadę proporcjonalności, wyrażoną w art. 31 ust. 3 zd. 1 Konstytucji RP, który stanowi, że ograniczenia w zakresie korzystania z konstytucyjnych wolności i praw mogą być ustanawiane tylko w ustawie i tylko wtedy, gdy są konieczne w demokratycznym państwie dla jego bezpieczeństwa lub porządku publicznego (...), albo wolności i praw innych osób.

Stanowisko akcentujące wymóg proporcjonalności jest od długiego czasu prezentowane w orzecznictwie sądów polskich i unijnych ${ }^{9}$. Już w 1992 r. Sąd Antymonopolowy wskazał, że z uwagi na zasadę praworządności i celowości działania administracji państwowej, na której opiera się postępowanie administracyjne, organ ochrony konkurencji nie może nakładać kary pieniężnej za nieudzielenie mu żądanych danych i informacji, jeżeli rzeczywiście nie są one przydatne do wydania decyzji administracyjnej. Sąd podkreślił zarazem, że działania organu muszą być zawsze celowe i służyć wykonaniu konkretnie oznaczonego zadania. Podobne podejście zastosował Sąd Ochrony Konkurencji i Konsumentów (dalej: SOKiK) w wyroku z 31 stycznia 2008 r. ${ }^{10}$, w którym zostało wskazane, że Prezes UOKiK jako organ władzy publicznej powinien działać zgodnie $z$ art. 7 Konstytucji RP na podstawie i w granicach prawa. Jest ono także akcentowane w doktrynie polskiego prawa konkurencji - żądane informacje powinny być więc faktycznie niezbędne dla danego postępowania (inaczej dojdzie do naruszenia zasady proporcjonalności) (Bernatt, 2011, s. 185 ; Kohutek, 2014, s. 774).

Dla wykładni przesłanki „konieczności” przydatne jest zwrócenie uwagi na dorobek unijnej judykatury, która dostarcza jasnych wytycznych co do sposobu prawidłowej wykładni przesłanki „konieczności”. Sąd Pierwszej Instancji (dalej: SPI) w wyroku w sprawie Omya AG ${ }^{11}$ wskazał, że

prawdą jest wreszcie, że wykonywanie przez Komisję uprawnień przyznanych jej na mocy art. 11 rozporządzenia nr 139/2004 uwarunkowane jest poszanowaniem zasady proporcjonalności, która wymaga, aby akty wydawane przez instytucje wspólnotowe nie przekraczały granic tego, co jest stosowne i konieczne do realizacji wyznaczonych celów (wyrok Sądu z dnia 4 lipca 2006 r. w sprawie T-177/04 easyJet przeciwko Komisji, Zb. Orz. s. II-1931, pkt 133). Ważne jest w szczególności, aby nałożony na przedsiębiorstwo obowiązek dostarczenia

\footnotetext{
Wyr. Sądów (wówczas Sądu Pierwszej Instancji) w sprawie T-39/90 SEP przeciwko Komisji, [1991] ECR II-1497, pkt. 29; wyr. Sądu Antymonopolowego z 19.11.1992 r., sygn. akt XVII Amr 24/92.

10 Wyr. SOKiK z 31.01.2008 r., sygn. akt XVII Ama 32/07, niepubl.

11 Wyr. SPI z 4.02.2009 r. w sprawie T-145/06.
}

internetowy Kwartalnik Antymonopolowy i Regulacyjny 2020, nr 3(9) • www.ikar.wz.uw.edu.pl • DOI: 10.7172/2299-5749.IKAR.3.9.5 
informacji nie stanowił dla niego obciążenia niewspółmiernego do potrzeb dochodzenia (zob. analogicznie wyrok Sądu z dnia 12 grudnia 1991 r. w sprawie T-39/90 SEP przeciwko Komisji, Rec. s. II-1497, pkt 51). ${ }^{12}$

SPI podniósł też, że w zakresie sądowej kontroli znajduje się kwestia nadużycia władzy i stwierdził, że sytuacja taka ma miejsce wówczas, gdy

organ administracyjny użył swoich uprawnień w celu odmiennym niż ten, w którym uprawnienia te zostały mu przyznane. ${ }^{13}$

Jeszcze dalej idący jest wyrok sądu w sprawie Slovak Telekom a.s. z dnia 22 marca 2012 roku ${ }^{14}$. W orzeczeniu tym potwierdzono, iż

żądania udzielenia informacji skierowane przez Komisję do przedsiębiorstwa powinny być zgodne z zasadą proporcjonalności i że nałożony na przedsiębiorstwo obowiązek dostarczenia informacji nie może stanowić dla niego obciążenia nieproporcjonalnego w stosunku do potrzeb dochodzenia. (zob. ww. w pkt 42 wyrok z dnia 12 grudnia 1991 r. w sprawie SEP przeciwko Komisji, pkt 51, 52; ww. w pkt 45 wyrok w sprawach połączonych Atlantic Container Line i in. przeciwko Komisji, pkt 418 i przytoczone tam orzecznictwo)

Na szczególną uwagę zasługuje fakt, że Sąd stanął na stanowisku, że

zgodnie z orzecznictwem, potrzeba ochrony przed arbitralną lub nieproporcjonalną ingerencją władz publicznych w sferę działalności prywatnej każdej osoby fizycznej bądź prawnej jest uznana za ogólną zasadę prawa Unii. ${ }^{15}$ (zob. podobnie wyrok Trybunału z dnia 21 września 1989 r. w sprawach połączonych 46/87 i 227/88 Hoechst przeciwko Komisji, Rec. s. 2859, pkt 19 i przytoczone tam orzecznictwo)

Wprost do przesłanki niezbędności unijny Sąd Pierwszej Instancji odniósł się w wyroku w sprawie NV Samenwerkende Elektriciteits-Produktiebedrijven v Commission of the European Communities z 12 grudnia 1991 r., T-39/90, [1991] ECR II - 1497, wskazując, że przewidziana w art. 11 ust. 1 rozporządzenia 139/2004 przesłanka niezbędności informacji powinna być interpretowana przez pryzmat celów, których realizacji służyć ma przyznanie Komisji Europejskiej relewantnych uprawnień. Sąd stwierdził też, że wymaganie istnienia związku między żądanymi informacjami a zarzucanym naruszeniem jest spełnione wówczas, gdy biorąc pod uwagę etap postępowania, prośba o ich udzielenie może rozsądnie być uznana za mającą związek z naruszeniem ${ }^{16}$.

\footnotetext{
Wyr. SPII w sprawie Omya AG, z 4.02.2009 r. w sprawie T-145/06, pkt 34.

13 Ibidem, pkt 99.

14 Wyr. Sądu w sprawie Slovak Telekom a.s., z 22.032012 r. w sprawach T-458/09 i T-171/10.

15 Ibidem, pkt 81.

16 It should be noted as a preliminary point in that regard that the term "necessary information" contained in Article 11(1) must be interpreted according to the objectives for the achievement of which the powers of investigation in question have been conferred upon the Commission. The requirement that there must exist a correlation between the request for information and the putative infringement is satisfied, since at that stage in the proceeding the request may legitimately be regarded as having a connection with the putative infringement. Wyr. w sprawie NV Samenwerkende ElektriciteitsProduktiebedrijven v Commission of the European Communities z 12.12.1991 r., T-39/90, [1991] ECR II - 1497, pkt 29.
} 


\section{Zakres obowiązku przedsiębiorcy}

W świetle powyższych uwag nie ulega wątpliwości, że uprawnienia Prezesa UOKiK, o których mowa w art. 50 ust. 2 uokik podlegają ograniczeniom. Należy jednak podkreślić, że możliwość powoływania się przez przedsiębiorcę na wspomniane ograniczenia w praktyce jest w dużym stopniu utrudniona.

Zgodnie z ugruntowanym poglądem wyrażanym w piśmiennictwie i znajdującym odzwierciedlenie w orzeczeniach sądowych, to organ antymonopolowy jest wyłącznie władny decydować jakie informacje i dokumenty są mu niezbędne do prowadzenia postępowania. Wspomniane stanowisko zajął m.in. SA w Warszawie ${ }^{17}$, w którym stwierdził, że

[...] art. 50 ustawy o ochronie konkurencji i konsumentów w zasadzie nie wyznacza zakresu przedmiotowego uprawnienia Prezesa Urzędu, np. przez wyliczenie spraw, w których mógłby on skorzystać z tego uprawnienia. Na podstawie powołanego przepisu Prezes Urzędu może więc żądać od przedsiębiorców przekazania mu wszelkich koniecznych informacji i dokumentów. Przy tym, ocena czy określona informacja jest konieczna, należy wyłącznie do Prezesa Urzędu, zaś przedsiębiorca nie może odmówić udzielenia żądanej przez organ informacji twierdząc, że jego zdaniem informacja ta nie jest związana z przedmiotem prowadzonego postępowania, nie jest zatem konieczna.

Aczkolwiek SA w Warszawie wskazał w przywołanym orzeczeniu, iż żądanie Prezesa UOKiK powinno być proporcjonalne, wspomniany i dość mocno ugruntowany w praktyce orzeczniczej pogląd, iż to Prezes UOKiK - jako "gospodarz postępowania” - jest wyłącznie uprawniony do zajmowania stanowiska w zakresie zasadności żądanych informacji może skutkować błędnym przekonaniem po stronie adresatów, że są oni zobligowani do podporządkowania się żądaniu w każdej sytuacji (nawet wówczas, gdy żądanie jest ewidentnie wadliwe, np. zawiera zbyt ogólne uzasadnienie).

Kluczowym aspektem jest jednak brak skutecznego instrumentu pozwalającego przedsiębiorcy zakwestionować zakres lub cel żądanych informacji lub dokumentów w toku postępowania, w ramach którego wystosowane zostało żądanie. Żądanie nie jest bowiem postanowieniem lub decyzją organu antymonopolowego, która mogłaby zostać zaskarżona do SOKiK. Weryfikacja prawidłowości żądania możliwa jest wówczas, gdy:

(i) przedsiębiorca odmówi przekazania danych żądanych przez Prezesa UOKiK;

(ii) przeprowadzone zostanie odrębne postępowanie w sprawie naruszenia obowiązku proceduralnego, w wyniku którego zostanie wydana decyzja (w praktyce najczęściej nakładająca kara pieniężną na przedsiębiorcę);

(iii) od wspomnianej decyzji przedsiębiorca złoży odwołanie do SOKiK, który dokonana weryfikacji czy żądanie organu antymonopolowego było zasadne.

Perspektywa nałożenia kary, która potencjalnie może wynieść równowartość 50 mln euro, sprawia, że niewielu przedsiębiorców jest skłonnych ryzykować spór z organem antymonopolowym dotyczący zakresu oraz celu żądania informacji i dokumentów. Po rozstrzygnięciu w sprawie EEMHS kwestionowanie żądań organu antymonopolowego wydaje się obarczone jeszcze większym ryzykiem niż dotychczas, gdyż sygnał wysłany przez Prezesa UOKiK jest jednoznaczny:

17 Wyr. SA w Warszawie z 1.032012 r. (VI ACa 1033/11). 
w przypadku braku współpracy surowa kara jest nieunikniona nawet wówczas, gdy przedsiębiorca powziął uzasadnione wątpliwości co do zasadności żądania. Powyższe okoliczności sprawiają, że obowiązek przekazywania danych na żądanie Prezesa UOKiK staje się de facto obowiązkiem o charakterze bezwzględnym, a odpowiedzialność przedsiębiorcy w przypadku niesprostania oczekiwaniom UOKiK absolutna. W praktyce - w przypadku żądań, które w ocenie przedsiębiorcy są wadliwe - możliwe jest oczywiście prowadzenie dialogu z organem antymonopolowym, np. w celu zawężenia zakresu żądania, ale to czy dialog ten faktycznie doprowadzi do pożądanych przez przedsiębiorcę rezultatów jest niepewne.

Bezpośrednią praktyczną konsekwencją jest zatem brak jest skutecznej „tarczy” chroniącej przed nadmierną ingerencją ze strony organu antymonopolowego. Może to zachęcać do formułowania bardzo szeroko zakrojonych żądań wzywających do przygotowania i przedłożenia opracowań (często według wzorca określonego przez Prezesa UOKiK), które wymagają zaangażowania wielu osób i są bardzo czasochłonne. W praktyce można również zetknąć się z wezwaniami, które nakładają obowiązek przedsiębiorcy do przedłożenia bardzo szczegółowych danych, które nie znajdują się w jego posiadaniu, ale istnieje duże prawdopodobieństwo, że dysponować nimi może przedsiębiorca należący do grupy kapitałowej adresata żądania. W tego typu przypadkach możliwe jest oczywiście podjęcie dialogu z Prezesem UOKiK w celu zawężenia zakresu żądania, ale decyzja w tym zakresie pozostaje całkowicie w gestii przedstawicieli organu antymonopolowego.

Do rozważania pozostaje zatem doprecyzowanie de lege ferenda art. 50 ust. 1 uokik tak, aby wprost wskazywał, że żądanie kierowane przez Prezesa UOKiK dotyczy wyłącznie informacji i dokumentów będących w posiadaniu adresata żądania. Rozwiązanie to pozostawałoby spójne z dotychczasowym orzecznictwem, w którym podkreśla się, że Prezes UOKiK może żądać od podmiotu gospodarczego informacji i danych będących w posiadaniu przedsiębiorcy ${ }^{18}$, nieprzekazanie zaś przez przedsiębiorcę informacji, które nie są w jego posiadaniu i które nie są znane przedsiębiorcy nie stanowi naruszenia art. 50 ust. 1 uokik $^{19}$. Dodatkowo, zarówno w orzecznictwie, jak i w literaturze przedmiotu wskazuje się, że Prezes UOKiK nie może żądać przekazania informacji oraz dokumentów w przypadku, gdy nie istnieje prawny obowiązek ich gromadzenia bądź udostępniania ${ }^{20}$, jak również materiałów, które nie obrazują działalności przedsiębiorcy i które niejako nie są „w zasięgu jego ręki”21.

Podstawowym postulatem de lege ferenda powinno być jednak zagwarantowanie środka odwoławczego od żądania kierowanego przez Prezesa UOKiK w trybie przeprowadzenia stosownych zmian legislacyjny. Wprowadzenie tego rozwiązania umożliwiłoby realną kontrolę nad rozstrzygnięciami Prezesa UOKiK dotyczącymi zakresu żądanych informacji i dokumentów. Byłoby jednocześnie spójne z rozstrzygnięciami uznającymi, że pozbawienie strony możliwości kontroli sądowej rozstrzygnięć organu antymonopolowego jest niekonstytucyjne ${ }^{22}$. Warto wreszcie zauważyć, że rozwiązanie to odpowiadałoby standardom przyjętym na szczeblu unijnym. Do katalogu KE, które podlegają możliwości zaskarżenia należą m.in. decyzje wydane na podstawie

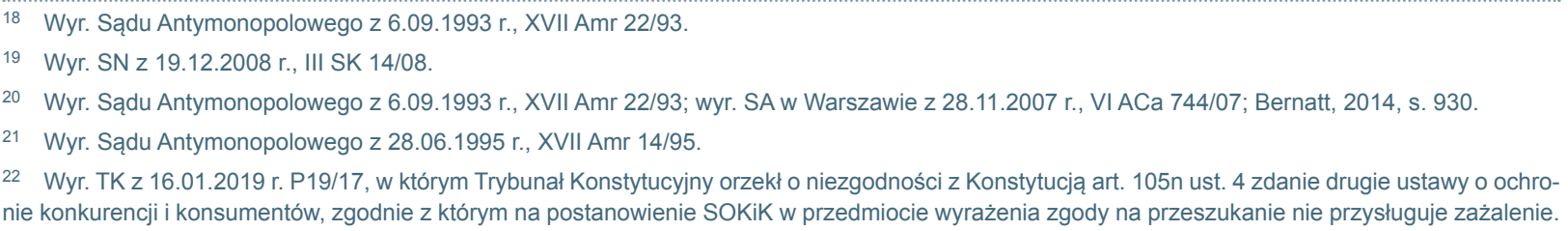


art. 18 rozporządzenia 1/2003 oraz decyzje kierowane do przedsiębiorców w związku z postępowaniami koncentracyjnymi.

Można oczywiście rozważyć rozwiązanie pośrednie polegające na wprowadzeniu do polskiego porządku prawnego instytucji urzędnika przeprowadzającego spotkanie wyjaśniające (hearing officer) funkcjonującej w ramach unijnych procedur egzekwowania prawa konkurencji. Instytucja ta obecnie jest regulowana decyzją Przewodniczącego Komisji Europejskiej w sprawie funkcji i zakresu uprawnień urzędnika przeprowadzającego spotkanie wyjaśniające w niektórych postępowaniach z zakresu konkurencji ${ }^{23}$. W preambule wspomnianej decyzji wskazano, że urzędnik ten działa jako

niezależny arbiter, który dążąc do rozwiązania kwestii mających wpływ na skuteczne wykonywanie praw procesowych zainteresowanych stron, innych stron uczestniczących, skarżących lub zainteresowanych osób trzecich (...).

Kompetencje urzędnika dzielą się zasadniczo na decyzyjne, sprawozdawcze oraz do wydawania zaleceń. Do najistotniejszych kompetencji decyzyjnych urzędnika należy podejmowanie decyzji w sprawach: o przedłużenie terminów wyznaczonych na ustosunkowanie się do pisemnego zgłoszenia zastrzeżeń, uzupełniającego pisemnego zgłoszenia zastrzeżeń lub opisu faktów bądź terminów (art. 4 ust. 2 lit. c w związku z art. 3 ust. 7 decyzji), udzielania informacji przedsiębiorstwom (i ich związkom) o statusie w prowadzonym postępowaniu wyjaśniającym (art. 4 ust. 2 lit. d w związku z art. 3 ust. 7 decyzji), wniosków o udzielenie dostępu do akt, dokumentów i informacji (art. 7 ust. 1 decyzji), sprzeciwów wobec ujawnienia informacji, które mogą stanowić tajemnicę handlową lub innego rodzaju informację poufną (art. 8 decyzji), jak również wniosków o wydłużenie terminu na udzielenie odpowiedzi na pisemne zgłoszenie zastrzeżeń (art. 9 ust. 1 decyzji) (Wils, 2012, s. 431-456). Zalecenia wydawane przez urzędnika dotyczą oceny w kwestii zastosowania w danym przypadku wolności od samooskarżenia (art. 4 ust. 2 lit. b w związku $z$ art. 3 ust. 7 decyzji).

Po przeprowadzonym spotkaniu urzędnik składa sprawozdanie ze spotkania właściwemu członkowi Komisji zawierające wnioski dotyczące skutecznego wykonywania praw procesowych. Złożenie Komisji sprawozdania końcowego wraz z proponowanym projektem decyzji w sprawie przez urzędnika ma zapewnić, że Komisja dysponuje wszelkimi istotnymi informacjami w zakresie przebiegu procedury oraz skutecznego wykonywania praw procesowych w toku całego postępowania.

W mojej ocenie ewentualne wprowadzenie instytucji hearing oficer - aczkolwiek byłby to niewątpliwy krok we właściwym kierunku - nie stanowi jednak alternatywy dla środka odwoławczego od żądania kierowanego przez Prezesa UOKiK. Ostateczne rozstrzygnięcia co do zasadności i celowości żądania pozostawałyby bowiem nadal w gestii organu antymonopolowego bez możliwości pełnej weryfikacji przez sąd.

\footnotetext{
23 Dec. Przewodniczącego Komisji Europejskiej z dnia 13 października 2011 r. w sprawie funkcji i zakresu uprawnień urzędnika przeprowadzającego spotkanie wyjaśniające w niektórych postępowaniach z zakresu konkurencji (2011/695/UE).
} 


\section{Sankcja za naruszenia obowiązku określonego w art. 50 ust. 1 uokik}

Jak wskazano powyżej, podstawowym czynnikiem zniechęcającym przedsiębiorców do podejmowania sporu z UOKiK co do zasadności żądania jest perspektywa surowej kary. W myśl art. 106 ust. 2 pkt 2 uokik, Prezes UOKiK może nałożyć na przedsiębiorcę, w drodze decyzji, karę pieniężną w wysokości stanowiącej równowartość do 50 mln euro, jeżeli przedsiębiorca ten choćby nieumyślnie nie udzielił informacji żądanych przez Prezesa UOKiK na podstawie art. 10 ust. 9 , art. 12 ust. 3 , art. 19 ust. 3, art. 23c ust. 3, art. 28 ust. 3 lub art. 50 uokik bądź udzielił nieprawdziwych lub wprowadzających w błąd informacji.

W opracowaniach dotyczących systemu kar pieniężnych obowiązującego w Polsce wskazuje się, że rozwiązanie polegające na ustanowieniu górnego pułapu kary poprzez odniesienie się do kwoty 50 mln euro budzi wątpliwości (Piszcz, 2013, s. 286). Trudno znaleźć racjonalny powód dlaczego w przypadku naruszeń proceduralnych ustawodawca zdecydował się, aby nie powiązać maksymalnego wymiaru kary z obrotem przedsiębiorcy (tak jak ma to miejsce w przypadku sankcji z tytułu naruszeń przepisów materialnoprawnych uokik). Rozwiązanie polegające na ustaleniu kwoty 50 mln euro jako maksymalnego progu sankcji obowiązuje od 2004 r. i nie było modyfikowane mimo kolejnych nowelizacji uokik.

W mojej ocenie podstawowym mankamentem braku powiązania maksymalnego pułapu kary z obrotem przedsiębiorcy jest ryzyko zbyt dużej dolegliwości kary w przypadku nakładania kar na mniejszych przedsiębiorców. Nałożenie kary, która nie jest zrelatywizowana do ich potencjału gospodarczego może spowodować daleko idące kłopoty finansowe, a w skrajnych przypadkach doprowadzić do upadłości. W doktrynie wskazuje się jednak na ryzyko zaistnienia sytuacji, w której nawet wówczas, gdy kara za naruszenie proceduralne będzie oscylować wokół górnego pułapu, o którym mowa w uokik, - nie będzie ona mogła spełniać swoich funkcji wobec dużych przedsiębiorców (Piszcz, 2013, s. 287).

Z powyższych względów przyjęcie obrotu przedsiębiorcy jako punktu odniesienia przy nakładaniu sankcji stanowiłoby docelowo pożądane rozwiązanie ustawowe. Można alternatywnie rozważyć wprowadzenie do istniejącej regulacji rozwiązania pośredniego, tak aby oprócz górnego pułapu określonego kwotowo funkcjonował równolegle próg relatywizowany do obrotu przedsiębiorcy (do rozważenia pozostaje czy próg ten powinien wynosić $10 \%$, czy też nie powinien on - wzorem rozwiązań przyjętych na gruncie przepisów unijnych - być określony na niższym poziomie).

Niezależnie od tego, jakie rozwiązanie zostanie ostatecznie przyjęte, górny pułap kary nie powinien być uznawany jako zasadniczy punkt odniesienia przy ustalaniu wysokości nałożonej kary. Powołany przepis przesądza jedynie o tym, iż na przedsiębiorcę nie może być w żadnym razie nałożona kara wyższa niż $50 \mathrm{mln}$ euro, nawet gdyby za takim rozwiązaniem przemawiały zasady proporcjonalności i efektywności. Ustalanie kar na poziomie zrelatywizowanym do górnego pułapu sankcji mogłoby doprowadzić do paradoksalnej sytuacji, w której kary za naruszenia proceduralne przewyższają w praktyce kary nakładane na przedsiębiorców za praktyki ograniczające konkurencję. Warto w tym kontekście wskazać, że kara nałożona na EEMHS, stanowiąca najwyższą karę w historii UOKiK, jest wyższa niż kary jednostkowe nakładane na uczestników długoletnich karteli (np. kartelu funkcjonującego w przemyśle cementowym) - żadna z kar nałożonych dotychczas 
przez Prezesa UOKiK za uczestnictwo w antykonkurencyjnym porozumieniu horyzontalnym nie przekroczyła 100 mln złotych.

Decyzja w sprawie EEMHS pokazuje jednocześnie, że przyjęcie pewnych założeń co do wysokości kary na podstawie dotychczasowych rozstrzygnięć Prezesa UOKiK obarczone jest wysokim ryzykiem błędu.

Postępowanie w sprawie nałożenia kary na EEMHS oraz wydane w tym postępowaniu rozstrzygnięcie nie są pierwszymi przypadkami zastosowania kary, o której mowa w art. 106 ust. 2 pkt 2 uokik. W okresie od 1 stycznia 2015 r. do dnia 6 listopada 2019 r. Prezes UOKiK wydał aż 22 decyzje na podstawie art. 106 ust. 2 pkt 2 uokik, w których nałożył na innych przedsiębiorców kary pieniężne ${ }^{24}$. Precedensowy jest jednak wymiar sankcji nałożonej na EEMHS, jeżeli uwzględnimy, że średnia wysokość kar pieniężnych nakładanych przez Prezesa UOKiK na przestrzeni ostatnich lat wyniosła 2010 euro, tj. 8626 zł. Najwyższa z nałożonych w analizowanym okresie kar wyniosła 6000 euro $^{25}$. Nałożona na EEMHS kara jest aż 6666-krotnie wyższa, aniżeli najwyższa z kar zastosowanych przez Prezesa UOKiK od 1 stycznia 2015 r. na podstawie art. 106 ust. 2 pkt 2 uokik. Co więcej, łączna suma kar nałożonych przez Prezesa UOKiK na 22 przedsiębiorców wynosi zaledwie 44231,24 euro, co daje kwotę niemal 1000-krotnie niższą niż sankcja nałożona na EEMHS.

Decyzja w sprawie EEMHS budzi zatem daleko idące wątpliwości, jeżeli uwzględnimy, że organ antymonopolowy bez uzasadnionej przyczyny nie powinien odstępować od utrwalonej praktyki rozstrzygania spraw. Zasada pewności prawa oraz zaufania do organów państwa, wynikająca z k.p.a., akcentowana jest w orzecznictwie antymonopolowym dotyczącym kar pieniężnych stosowanych przez Prezesa UOKiK. W orzecznictwie zauważa się, że przy określaniu wysokości kar

nie bez znaczenia jest zasada sformułowana w art. 8 k.p.a., tj. zasada zaufania do władzy publicznej. Przepisy prawa, które w tym wypadku muszą być uwzględnione przez Prezesa UOKiK to art. 106 ust. 2 w zw. z art. 111 Ustawy. Wskazane jest również, aby Prezes UOKiK oparł się na swoim dotychczasowym orzecznictwie w zakresie kar pieniężnych, jak również publikowanych stanowiskach i wytycznych, gdyż to stanowi realizację zasady zaufania do władzy publicznej. 26

Warto w tym kontekście wskazać, że w przeszłości sądy uznawały kary o wiele niższej wysokości za adekwatne sankcje w odniesieniu do naruszeń o charakterze proceduralnym. Sąd Ochrony Konkurencji i Konsumentów uznał, że kara w wysokości 10000 euro będzie wystarczająca, aby oddziaływać represyjnie oraz prewencyjnie na sprawcę naruszeń27. W orzecznictwie Sądu Apelacyjnego kara w wysokości 198015 zł (50000 euro) została potraktowana jako sankcja, która nie jest niska i spełnia funkcję represyjną, prewencyjną i edukacyjną przy zachowaniu wymogu proporcjonalności ${ }^{28}$. Z kolei według Sądu Najwyższego kwota kary pieniężnej w wysokości 80000 zł spełnia swoją funkcję, nawet w sytuacji, gdy przedsiębiorca nie udzielił informacji, pomimo trzykrotnego wezwania Prezesa UOKiK.

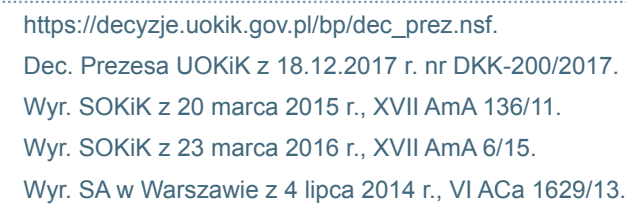


Należy jednocześnie wskazać, że wymierzając karę EEHMS zostały uwzględnione okoliczności nie brane dotychczas pod uwagę w związku z wymierzaniem kar na przedsiębiorców przez UOKiK. W myśl art. 111 ust. 1 pkt 3 uokik, Prezes UOKiK, ustalając wysokość nakładanej kary pieniężnej, uwzględnia w szczególności okoliczności naruszenia przepisów ustawy oraz uprzednie naruszenie przepisów ustawy, a także, w przypadku kary pieniężnej, o której mowa art. 106 ust. 2 uokik, wpływ naruszenia na przebieg i termin zakończenia postępowania. Wydając decyzję o nałożeniu kary pieniężnej, Prezes UOKiK powinien kierować się kryteriami określonymi w art. 111 uokik oraz zasadami równości i proporcjonalności. Konieczność poszanowania zasady proporcjonalności jest mocno akcentowana w orzecznictwie. Sąd Najwyższy w jednym z niedawnych wyroków wskazał, że

wymierzając karę trzeba mieć przede wszystkim na względzie zasadę proporcjonalności (art. 31 ust. 1 Konstytucji RP), tj. aby kara była proporcjonalna do rodzaju i szkodliwości konkretnej praktyki oraz skutków przez nią wywołanych (wyrok Sądu Najwyższego z dnia 19 września 2009 r., III SK 5/09). Zasada proporcjonalności ma również znaczenie w innym aspekcie, uzasadniając wyłącznie sankcje o stopniu dolegliwości niezbędnym dla osiągnięcia zamierzonego celu". Sąd Najwyższy wskazuje jednocześnie, że dla zapewnienia funkcji represyjnej i prewencyjnej kara powinna być zindywidualizowana, powinna zostać jednocześnie zapewniona „konieczność ekonomicznej odczuwalności kary w stosunku do zakresu (skali) działalności przedsiębiorcy i rentowności tej działalności.

Odnosząc się do ustawowego katalogu przesłanek wymiaru kary, nie ulega wątpliwości, że jest to katalog otwarty. Nie powinno to jednak przesądzać o dowolności w zakresie kreowania nowych, pozaustawowych kryteriów zwłaszcza w sytuacji, w której ich zastosowanie miałoby doprowadzić do zaostrzenia kary.

Niebezpiecznym precedensem jest tu rozstrzygnięcie w sprawie EEMHS, w którym obrót grupy kapitałowej, do której należy ten przedsiębiorca miał zasadnicze znaczenie dla wymiaru kary. Wymierzając kary dla EEMHS Prezes UOKiK stwierdził, że

Organ antymonopolowy przy ustalaniu wysokości kary uwzględnił także potencjał finansowy Engie. Jej obrót wyniósł w 2018 r. ok. [tajemnica przedsiębiorstwa] mln euro. Należy jednak podkreślić, iż obroty grupy kapitałowej, do której należy Engie były znacznie wyższe i wyniosły ok. 60 miliardów euro. Kara w mniejszej wysokości w ocenie organu antymonopolowego nie spełniłaby zatem w szczególności swej funkcji prewencyjnej i represyjnej w stosunku do Engie.

Rozstrzygnięcie w tym zakresie, uwzględniające obrót grupy kapitałowej przedsiębiorcy, jako punkt odniesienia przy wymierzaniu kary, należy uznać za precedensowe. Dotychczas - oprócz jednego, odosobnionego przypadku ${ }^{29}$ - Prezes UOKiK uwzględniał przy wymierzaniu kary wyłącznie obrót przedsiębiorcy, który naruszył przepisy uokik. Rozstrzygnięcie to jednocześnie stoi w jaskrawej sprzeczności z regułą przyjętą w obecnie obowiązujących przepisach, które wiążą

\footnotetext{
29 W decyzji z 2009 r. Prezes UOKiK obliczył wysokość kary, biorąc pod uwagę „potencjał gospodarczy” grupy kapitałowej przedsiębiorstwa uznanego za winnego naruszenia prawa konkurencji. Sprawa dotyczyła spółki holdingowej z grupy Carrefour, która została oskarżona o niewdrożenie w określonym terminie środków zaradczych w zakresie kontroli połączeń przedsiębiorstw. UOKiK argumentował, że spółka holdingowa miała niewielki obrót. W związku z tym, aby grzywna mogła spełniać swoją funkcję, konieczne było jej zwiększenie, biorąc pod uwagę obecność gospodarczą grupy Carrefour w Polsce w 2008 r. oraz związane z nią obroty przekraczające 2 mld PLN. Decyzja ta została następnie utrzymana w mocy przez polskie sądy.
} 
wysokość sankcji z obrotem przedsiębiorcy, który dopuścił się naruszenia, a nie z obrotem grupy kapitałowej, do której należy. Trudne do zaakceptowania jest zatem podejście, w którym podstawowa zasada dotycząca wymiaru kary jest modyfikowana ze względu na subiektywne przekonanie organu antymonopolowego co do zakresu dolegliwości sankcji dla przedsiębiorcy, który w konkretnym przypadku należałoby uznać za adekwatny dla spełnienia represyjnej funkcji kary.

Co więcej, bardzo niepokojące jest, że samo kwestionowanie rozstrzygnięć organu antymonopolowego może być przyczynkiem do zaostrzenia sankcji na przedsiębiorcy (vide decyzja ws. EEHMS), gdyż jest postrzegana nie jako próba podjęcia dialogu dotyczycącego zasadności żądania, lecz wyraz obstrukcji - umyślnego nieudzielenia informacji. Należy postawić pytania, czy wejście w spór z organem i nieuczynienie zadość jego żądaniu nie jest wystarczającą podstawą do przypisania przedsiębiorcy winy w jakiejkolwiek postaci, a w szczególności winy umyślnej. O winie adresata żądania można zasadnie mówić dopiero, gdy jego zachowanie odbiega od wzorca podmiotu należycie starannego i sumiennego, w wypełnianiu swych obowiązków. W tak skonstruowany model należycie starannego przedsiębiorcy nie powinno się moim zdaniem wpisywać założenia, iż powinien on uczynić zadość każdemu wezwaniu na podstawie art. 50 ust. 1 uokik nawet, gdy dołożył on należytej staranności przy rekonstrukcji treści normy prawnej i w oparciu o nią miał rozsądne podstawy by przypuszczać, iż żądanie Prezesa UOKiK jest niezasadne. Dla przypisania winy umyślnej niezbędne byłoby natomiast stwierdzenie, że miał on świadomość prawnej skuteczności wezwań i świadomie podjął decyzję o niepodporządkowaniu się mu.

\section{Podsumowanie}

Analiza szczegółowych polskich unormowań dotyczących egzekwowania prawa konkurencji przez UOKiK wskazuje, że na bardzo ważnych płaszczyznach gwarancje dostępu do skutecznego środka odwoławczego jest iluzoryczne. W tym kontekście wskazać należy w szczególności na fakt, że podmiot, wobec którego Prezes UOKiK wystosuje żądanie udostępnienia informacji lub dokumentów, w trybie art. 50 uokik, nie ma żadnej możliwość zakwestionowania jego legalności, bez narażania się na ryzyko zapłaty, niekiedy horrendalnie wygórowanej kary. Innymi słowy, podmiot, który uważa, iż żądanie Prezesa UOKiK jest bezprawne staje przed alternatywą, dostosować się bezwarunkowo do niego, czy też odmówić jego realizacji i przyjąć na siebie ryzyko zapłaty kary, w przypadku, gdyby sąd nie podzielił jego stanowiska. Wskazane ryzyko może nierzadko skłonić racjonalnych przedsiębiorców do akceptacji bezprawnie nakładanych na nich zobowiązań nawet w przypadkach, w których faktycznie doszło do naruszenia praw podstawowych przez organ antymonopolowy. Scharakteryzowany mechanizm de lege lata narusza prawo do sądu, gwarantowane na poziomie konstytucyjnym i konwencyjnym.

\section{Bibliografia}

Banasiński, C. i Piontek, E. (red.). (2009). Ustawa o ochronie konkurencji i konsumentów. Komentarz. Warszawa: Wolters Kluwer.

Bernatt, M. (2011). Sprawiedliwość proceduralna w postępowaniu przed organem ochrony konkurencji. Warszawa: Wydawnictwo Naukowe Wydziału Zarządzania Uniwersytetu Warszawskiego. 
Kohutek, K. (2014). W: K. Kohutek, M. Sieradzka, Ustawa o ochronie konkurencji i konsumentów. Komentarz. Warszawa: Wolters Kluwer.

Kruger, J. (2016). W: A. Stawicki, A. i Stawicki, E. (red.), Ustawa o ochronie konkurencji i konsumentów Komentarz. Warszawa: Wolters Kluwer.

Martysz, Cz. (2009). W: Jurkowska, A., Miąsik, D. i Skoczny, T. (red.), Ustawa o ochronie konkurencji i konsumentów. Komentarz. Warszawa: C.H. Beck.

Piszcz, A. (2013). Sankcje w polskim prawie antymonopolowym. Białystok: Temida 2.

Skoczny, T. (red.). (2014). Ustawa o ochronie konkurencji i konsumentów. Komentarz. Warszawa: C.H. Beck.

Wouter, P. i Wils, J. (2012). The Role of the Hearing Officer in Competition Proceedings Before the European Commission. World Competition: Law and Economics Review, 35(1). 